\title{
DMSO-TiCl $_{4}(1: 1)$ 錯体によるニ, 三のベンゾインの酸化 ${ }^{1)}$
}

(1985 年 9 月 28 日 受理)

\author{
山本二郎*・福 島隆広
}

\section{1 緒言}

Dyke と Pritchard ${ }^{2)}$ は無水酢酸中 DMSO の存在下でベンゾ イン〔1], p-トルオイン〔2]および 2,2'-フロイン〔6]を 酸化してそれぞれ相当するベンジルを得ている。著者らは最近

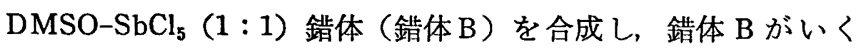
つかのベンゾインに対して強い酸化作用をもつことを見いだし だ)。

本報では $\mathrm{DMSO}-\mathrm{TiCl}_{4}(1: 1)$ 錯体（錯体 $\mathrm{A}$ ) が錯体 $\mathrm{B}$ と同様に 三，三のベンゾインに対して簡便な酸化剂になり得るかどらかを 検討し, 経済性についても比較した。錯体 Aは[1], [2]，o-アニ

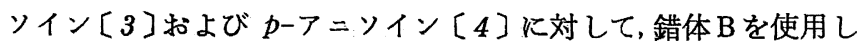



\section{2 実験}

\section{$2.1 p$-トルオイン[2]の合成 ${ }^{4)}$}

4-トルアルデヒドのエタノール溶液とシアン化カリウム水溶液 を混合し $40^{\circ} \mathrm{C}$ から $50^{\circ} \mathrm{C}$ で 2 時間反応させた。反応混合物を 水蒸気蒸留したのち, 析出した沈殷をエタノールで再結晶して

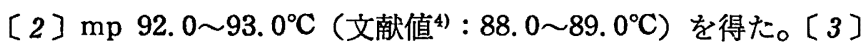
$\mathrm{mp} 93.0 \sim 94.0^{\circ} \mathrm{C}$ (文献值) ${ }^{5)}$ 99.0 $100.0^{\circ} \mathrm{C}$ ) および $4,4^{\prime}$-ジク ロロベンゾイン〔5] $\mathrm{mp} 88.0 \sim 89.0^{\circ} \mathrm{C}$ (文献值 ${ }^{6)}: 88.0^{\circ} \mathrm{C}$ ) む同

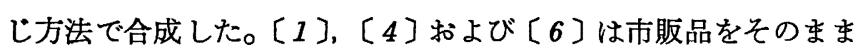
使用した。

\subsection{DMSO- $\mathrm{TiCl}_{4}(1: 1)$ 錯体（錯体 A) の合成}

DMSO $0.70 \mathrm{~g}(9.0 \mathrm{mmol})$ と $\mathrm{TiCl}_{4} 1.71 \mathrm{~g}(9.0 \mathrm{mmol})$ のそ れぞれの四塩化炭素溶液 $(10 \mathrm{~m} l)$ を混合するとただちに結晶が析 出した。反応混合物を一昼夜放置後沪過し四塩化炭素, ついで石 油エーテルで洗浄して黄色の錯体 $2.20 \mathrm{~g}(91.5 \%), \mathrm{mp} 218.5^{\circ} \mathrm{C}$ を得た。

IR $\left(\mathrm{cm}^{-1}\right): 1620,1405,1260,900,820,480,460$ 分析值 C $9.16 \%$, H $2.43 \%$

鳥取大学工学部工業化学科, 680 鳥取市湖山町

1)この報文を“DMSO- $\mathrm{TiCl}_{4}(1: 1)$ 錯体の反応性に関する 研究 (第 1 報)”とする.

2) M. V. Dyke, N. D. Pritchard, J. Org. Chem., 32, 3204(1967).

3) J. Yamamoto, S. Ito, T. Tsuboi, T. Tsuboi, K. Tsukihara, Bull. Chem. Soc. Jpn., 58, 470(1985).

4) T. Ekecrantaz, A. Ahlquist, Chem. Zentralbl., 1908, II 1689.

5) J. C. Irvine, J. Chem. Soc., 79, 668(1901).

6) W. H. Glower, A. Hantzsch, Chem. Ber., 40, 1519 (1907).
$\mathrm{C}_{2} \mathrm{H}_{8} \mathrm{SOTiCl}_{4}$ としての

計算值 C $9.00 \%, \mathrm{H} 2.24 \%$

\section{3 錯体 A によるベンソイン〔1]の酸化}

〔1] $1.0 \mathrm{~g}(4.7 \mathrm{mmol})$ と錯体 A $0.3 \mathrm{~g}(1.2 \mathrm{mmol})$ をニト口 メタン $(20 \mathrm{ml})$ に溶解し, 室温で 15 洔間放置した。反応混合物 に水を加光析出した沈殷を汇過してベンジル〔7〕を得た。一方， 沪液をベンゼン抽出し，ベンゼン溶液を故燥して濃縮したのちカ ラムクロマトグラフィー(シリカゲルーベンゼン)により〔1〕と 〔7〕とに分離した。沈殿7)とベンゼン溶液とから得られた〔7] は $0.96 \mathrm{~g}(97.0 \%) \mathrm{mp} 96.0 \sim 97.0^{\circ} \mathrm{C}$ (文献值 ${ }^{8)}: 95.0^{\circ} \mathrm{C}$ ) であっ た。〔2]，〔3]，〔4]，〔5]および〔6]と錯体 A との反応，お よび〔1]と錯体 B との反応も同じ操作で行なった。各種ベンジ ルは〔7〕を得る方法 ${ }^{8}$ に基づいて別途に合成し，それぞれ $\mathrm{mp}$ と IR を比較して同定した。

\section{4 ベンソイン〔1]と塩化水素との反応}

〔 1] $1.0 \mathrm{~g}(4.7 \mathrm{mmol})$ をニトロメタン $(20 \mathrm{ml})$ に溶かし乾燥 塩化水素を導入した。反応混合物を水洗して乾燥し, ニトロメタ ソを減圧で留去したのちベンゼンに溶解した。反応混合物をカラ ムクロマトグラフィー (シリカゲル-ベンゼン)により〔7 に $0.160 \mathrm{~g}(16.2 \%)$ と〔 1$] 0.787 \mathrm{~g}(78.7 \%)$ とに分離した。

\section{3 結果之考察}

X線結晶構造解析によると, 錯体 B のアンチモン原子はDMSO の酸素原子と直接結合し, 硫黄と酸素間の二重結合性が小さい構 造をとっている ${ }^{3)}$ 。錯体 A も同様にチタン原子と DMSO の酸素 原子とが直接結合して，一種のベタインを形成していると推定さ れる $\left[\left(\mathrm{CH}_{3}\right)_{2} \stackrel{+}{\mathrm{S}}-\mathrm{O}-\overline{\mathrm{TiCl}}{ }_{4}\right]$ 。

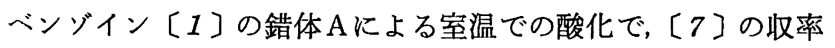
の向上をはかって最適反応時間を検討した。15 時間後に $97.0 \%$ の〔7〕が得られ〔1]が見いだされなかったので，同じ条件で 〔2]，〔3〕㧊よび〔4]と錯体A との反応を行なったところ，い ずれの場合も相当するベンジルが $92 \%$ 以上の収率で得られた （図 1, 表 1)。しかしながら〔5〕と錯体Aを加熱還流の条件下 で反応させても $84.3 \%$ の〔5]を回収し生成物は得られなかっ た。また[6]の錯体 Aによる酸化では, 室温でもタールを多く 生成するので, $0^{\circ} \mathrm{C}$ 付近で反応を行なって $39.1 \%$ の $2,2^{\prime}-$ フリル

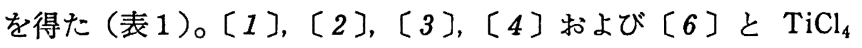

7) 沈殿は［7]のみで［1]は含まれていなかった（TLC： シリカゲルーベンゼン).

8) H. T. Clease, E. E. Dreger, "Organic Synthesis", Coll. Vol. I (1941) p. 87.

9）この反応で得た生成物の IR は, 標品 [7]の IR と一致 した。 


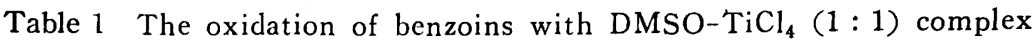

\begin{tabular}{|c|c|c|c|c|c|c|c|c|}
\hline \multirow{2}{*}{ 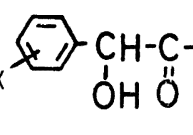 } & & \multirow{2}{*}{ Complex } & \multirow{2}{*}{$\begin{array}{l}\text { Molar tatio } \\
\text { (Complex/ } \\
\text { Benzoins) }\end{array}$} & \multicolumn{2}{|c|}{ Reaction conditions ${ }^{a}$} & \multirow{2}{*}{$\begin{array}{c}\text { Benzils } \\
(\%)\end{array}$} & \multirow{2}{*}{$\begin{array}{c}\text { Tarry product } \\
(\%)\end{array}$} & \multirow{2}{*}{$\begin{array}{l}\text { Recovered } \\
\text { benzoins } \\
(\%)\end{array}$} \\
\hline & & & & Temp. $\left({ }^{\circ} \mathrm{C}\right)$ & $\begin{array}{l}\text { Time } \\
\text { (h) }\end{array}$ & & & \\
\hline \multirow{6}{*}{\multicolumn{2}{|c|}{$\mathrm{H}[1]$}} & A & 0.127 & Room temp. & 17 & 55. 6 & Not detected & 33.7 \\
\hline & & A & 0.127 & Room temp. & 17 & $70.8^{b)}$ & Not detected & 21.8 \\
\hline & & A & 0.250 & Room temp. & 15 & $97.0(90.4)^{c)}$ & Not detected & Not detected \\
\hline & & A & 0.250 & Room temp. & 7 & $98.3^{(d)}$ & Not detected & Not detected \\
\hline & & B & 0.250 & Room temp. & 24 & 46. 4 & Not detected & 48.7 \\
\hline & & $B$ & 0.500 & Room temp. & 15 & 95.0 & Not detected & Not detected \\
\hline $4,4^{\prime}-\mathrm{CH}_{3}$ & {$[2]$} & A & 0.250 & Room temp. & 15 & $92.4(26.2)$ & Not detected & Not detected \\
\hline $2,2^{\prime}-\mathrm{OCH}_{3}$ & {$[3]$} & A & $0: 250$ & Room temp. & 15 & $94.1(29.5)$ & Not detected & Not detected \\
\hline $4,4^{\prime}-\mathrm{OCH}_{3}$ & {$[4]$} & A & 0.250 & Room temp. & 15 & $96.7(91.5)$ & Not detected & Not detected \\
\hline $4,4^{\prime}-\mathrm{Cl}$ & {$[5]$} & A & 0.250 & Reflux & 15 & Not detected & 6.4 & 84.3 \\
\hline $2,2^{\prime}-$ Furoin & {$[6]$} & A & 0.250 & $0 \sim 2$ & 2 & $39.1(11.6)$ & 31.3 & 10.7 \\
\hline
\end{tabular}

a) Nitromethane $(20 \mathrm{ml})$ was used as a solvent in each run.

b) After a mixture of [1] and complex $\mathrm{A}$ was allowed to stand for $17 \mathrm{~h}$, dry hydrogen chloride was passed through the reaction mixture for $4 \mathrm{~h}$.

c) In parentheses, the yield of benzils in the oxidation of benzoins using $\mathrm{TiCl}_{4}$ as an oxidizing agent is given.

d) Tribenzylamine $(0.33 \mathrm{~g}, 0.115 \mathrm{mmol})$ was added in this reaction.

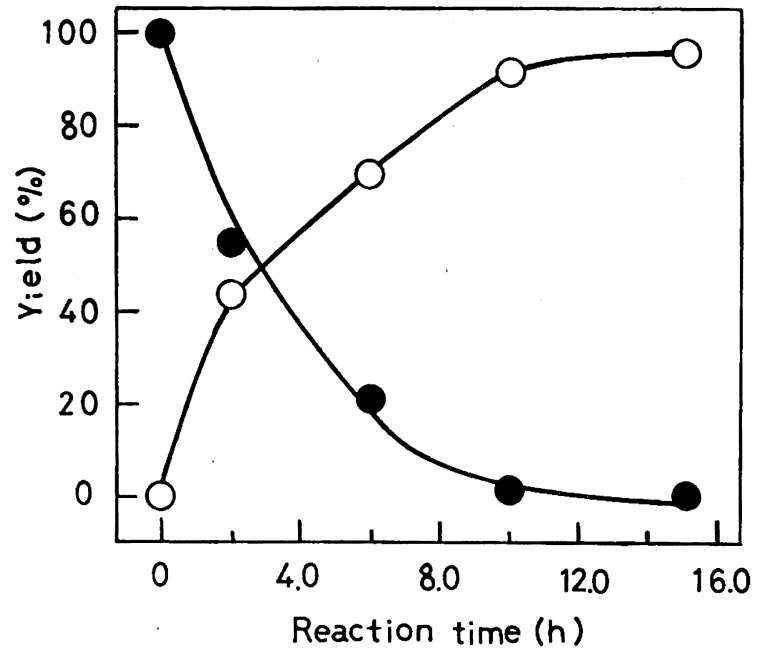

Fig. 1 The reaction time dependence in oxidation of

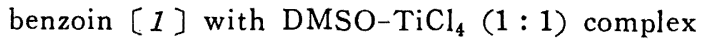

Reaction conditions: Benzoin $1.0 \mathrm{~g}(4.7 \mathrm{mmol})$, Complex $\mathrm{A} /[1]=0.25$, In nitromethane $(20 \mathrm{ml})$ at room temperature

$$
\bigcirc: \text { Benzil [7], : Benzoin [1] }
$$

との反応の結果を表 1 に示す。いずれの反応からも相当するベン ジルが生成した。 $\mathrm{TiCl}_{4}$ を用いた〔1]と〔4]の酸化でもそれぞ れのベンジルが $90 \%$ 以上の収率で得られたので, $\mathrm{TiCl}_{4}$ b〔1]

と〔4]の酸化剤として使用可能である。

反応進行中における着色变化が錯体 $\mathrm{A}$ と $\mathrm{TiCl}_{4}$ との場合とはま ったく異なることと、錯体 $\mathrm{A}$ を使用したときと $\mathrm{TiCl}_{4}$ を用いたと きとでは, ベンゾインの種類によりベンジルの収率にいちじるし い相迋があることから，両者の反応経路は異なっていると考えて

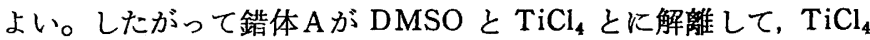
がベンゾインを酸化する可能性は少ない。錯体 $\mathrm{A}$ と〔1〕との二 トロメタン溶液にアンモニア水を近づけると塩化アンモニウムが 検出されたので, 反応の途中で塩化水素が発生している。また反 応混合物から硫化ジメチルが検出されており（ガスクロマトグラ フィー), この反応で水も生成したと思われる。以上のことから つぎのよらな化学量論で反応が進行すると考えられる。

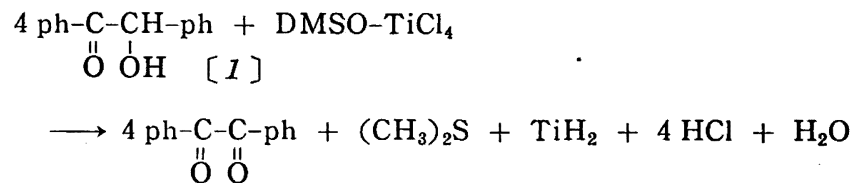

低いモル比（錯体/[1]=0.127）での反応において，55.6\%の 〔7〕が得られ，予想された最高収率を上まわった（表 1 ）。上に 述べたと同じ反応（錯体/[1]=0.127）を行なったのち, 反応混合 物に乾燥塩化水素を通ずると〔7〕の収率が $70.8 \%$ に向上した （表 1 ）。また[1]のニトロメタン溶液に㛺燥塩化水素を 5 時間 通ずると $16.2 \%$ の〔7〕を得, $78.7 \%$ の〔 1 〕を回収した。し たがって〔1]と錯体 A との反応中に生成した塩化水素が，〔1] の酸化に若干関与していると推定される。一方, 反応系から生成 した塩化水素を取除き，反応を速く進める試みとして，反応系に トリベンジルアミンを添加すると反応は 7 時間で完結した（表 1)。

[1]の錯体 B による酸化（モル比：錯体 $\mathrm{B} /[1]=0.5$ ）では 〔7〕が $95.0 \%$ 得られたものの, モル比（錯体 B/[1]）が0. 25 のときは，〔7〕の収率が 46.6\% に低下した（表 1 )。このこと

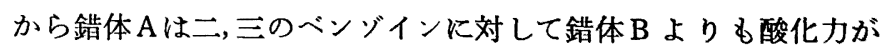
強く，経済的にも有利な酸化削といえる。 


\title{
The Oxidation of some Benzoins with DMSO-TiCl $4(1: 1)$ Complex $^{\dagger}$
}

\author{
Jiro Yамамото* and Takahiro Fukushima \\ Department of Industrial Chemistry, Faculty of Engineering, Tottori \\ University; Koyama-cho, Tottori-shi 680 Japan
}

When equimolar solutions of $\mathrm{DMSO}$ and $\mathrm{TiCl}_{4}$ in carbon tetrachloride were mixed, DMSO- $\mathrm{TiCl}_{4}(1: 1)$ complex (complex A) $\left(\mathrm{mp} 218.5^{\circ} \mathrm{C}\right.$ ) deposited immediately in $91.5 \%$ yield. The oxidation of benzoin [ 1$], p$-toluoin [2], $o$-anisoin [3] and $p$-anisoin [4] with complex A gave the corresponding benzils in more than $92 \%$ yield under mild conditions [room temperature, $15 \mathrm{~h}$, molar ratio (complex A/benzoins) $=0.25]$ (Table 1). The reaction of [1] with complex A was accelated by adding slight amounts of tribenzylamine (Table 1).

$\dagger$ Studies on Reactivity of DMSO-TiCl 4 (1:1) Complex. I. 